\title{
Metal Ion Requirements for Structure and Catalysis of an RNA Ligase Ribozyme ${ }^{\dagger}$
}

\author{
Margaret E. Glasner, Nicholas H. Bergman, and David P. Bartel* \\ Whitehead Institute for Biomedical Research and Department of Biology, MIT, 9 Cambridge Center, \\ Cambridge, Massachusetts 02142
}

Received December 20, 2001; Revised Manuscript Received April 25, 2002

\begin{abstract}
The class I ligase, a ribozyme previously isolated from random sequence, catalyzes a reaction similar to RNA polymerization, positioning its $5^{\prime}$-nucleotide via a Watson-Crick base pair, forming a $3^{\prime}, 5^{\prime}$-phosphodiester bond between its 5'-nucleotide and the substrate, and releasing pyrophosphate. Like most ribozymes, it requires metal ions for structure and catalysis. Here, we report the ionic requirements of this self-ligating ribozyme. The ligase requires at least five $\mathrm{Mg}^{2+}$ for activity and has a $\left[\mathrm{Mg}^{2+}\right]_{1 / 2}$ of 70-100 mM. It has an unusual specificity for $\mathrm{Mg}^{2+}$; there is only marginal activity in $\mathrm{Mn}^{2+}$ and no detectable activity in $\mathrm{Ca}^{2+}, \mathrm{Sr}^{2+}, \mathrm{Ba}^{2+}, \mathrm{Zn}^{2+}, \mathrm{Co}^{2+}, \mathrm{Cd}^{2+}, \mathrm{Pb}^{2+}, \mathrm{Co}\left(\mathrm{NH}_{3}\right)_{6}{ }^{3+}$, or spermine. All tested cations other than $\mathrm{Mg}^{2+}$, including $\mathrm{Mn}^{2+}$, inhibit the ribozyme. Hill analysis in the presence of inhibitory cations suggested that $\mathrm{Ca}^{2+}$ and $\mathrm{Co}\left(\mathrm{NH}_{3}\right)_{6}{ }^{3+}$ inhibit by binding at least two sites, but they appear to productively fill a subset of the required sites. Inhibition is not the result of a significant structural change, since the ribozyme assumes a nativelike structure when folded in the presence of $\mathrm{Ca}^{2+}$ or $\mathrm{Co}\left(\mathrm{NH}_{3}\right)_{6}{ }^{3+}$, as observed by hydroxyl-radical mapping. As further support for a nativelike fold in $\mathrm{Ca}^{2+}$, ribozyme that has been prefolded in $\mathrm{Ca}^{2+}$ can carry out the self-ligation very quickly upon the addition of $\mathrm{Mg}^{2+}$. Ligation rates of the prefolded ribozyme were directly measured and proceed at $800 \mathrm{~min}^{-1}$ at $\mathrm{pH} 9.0$.
\end{abstract}

Metal ions are essential for the activity of most ribozymes, functioning in electrostatic shielding, structure, and directly in catalysis (1). Natural ribozymes vary widely in their metal ion specificity, from the large ribozymes (group I intron, group II intron, and RNase $\mathrm{P}^{1}$ ), which require a divalent metal, preferably $\mathrm{Mg}^{2+}$, for activity, to the promiscuous selfcleaving ribozymes (hammerhead, hairpin, VS, and HDV), which are active in many different cations $(2-13)$. Hammerhead, hairpin, and VS ribozymes are even active in nonmetal ions such as $\mathrm{NH}_{4}{ }^{+}(12,13)$. Ribozymes selected in vitro also exhibit a wide range of metal ion requirements. Some, like the ribonucleolytic leadzyme, are active only in the cations in which they were selected $(14-16)$. Others exhibit activity in the presence of metal ions which were not present during their selection. For example, an acyl transferase ribozyme, which was selected in the presence of $\mathrm{Mg}^{2+}$ and $\mathrm{K}^{+}$only, is active in a wide variety of cations, including $\mathrm{Co}\left(\mathrm{NH}_{3}\right)_{6}{ }^{3+}(17,18)$.

The class I ligase, which was also selected in the presence of only $\mathrm{Mg}^{2+}$ and $\mathrm{K}^{+}$, performs a reaction similar to RNA polymerization, positioning its $5^{\prime}$-nucleotide via a WatsonCrick base pair, forming a 3',5'-phosphodiester bond between its $5^{\prime}$-nucleotide and the substrate, and releasing pyrophosphate (Figure 1) (19). In fact, a version of this ribozyme

†This work was supported by a grant from the NIH. M.E.G. was a Howard Hughes Medical Institute Predoctoral Fellow.

* Corresponding author. Fax: 617-258-6768. E-mail dbartel@wi.mit.edu.

${ }^{1}$ Abbreviations: EDTA, ethylenediaminetetraacetic acid; EGTA, ethylene glycol-bis[ $\beta$-aminoethyl ether]- $N, N, N^{\prime}, N^{\prime}$-tetraacetic acid; MES, 2-[ $N$-morpholino] ethanesulfonic acid; BES, $N, N$-bis[2-hydroxyethyl]-2-aminoethanesulfonic acid; EPPS, $N$-[2-hydroxyethyl]piperazine- $N$-[3-propanesulfonic acid]; CHES, 2-[ $N$-cyclohexylamino]ethanesulfonic acid; RNase $\mathrm{P}$, ribonuclease $\mathrm{P}$.

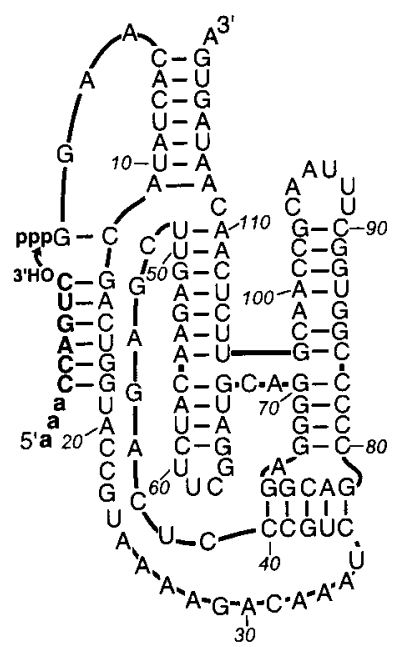

FIGURE 1: Secondary structure of the class I ligase. The ribozyme catalyzes the attack of the $3^{\prime}-\mathrm{OH}$ of the substrate on its $5^{\prime}$ triphosphate, forming a $3^{\prime}, 5^{\prime}$-phosphodiester bond and releasing pyrophosphate.

can act as a general RNA polymerase, accurately extending a primer up to 14 nucleotides (20). Not only does the ligase perform the same reaction as naturally occurring RNA and DNA polymerases, but the stereospecificity of its preference for sulfur substitutions at the nonbridging oxygens on the $\alpha$-phosphate matches that of these enzymes, raising the possibility that a catalytic mechanism common to all polymerases extends to ribozyme-mediated polymerization as well $(21,22)$. The ligase is also one of the fastest ribozymes, among both natural ribozymes and those selected in vitro (23). These characteristics raise a number of interesting questions, including how the ligase's metal ion requirements compare to that of other ribozymes, how these requirements 
compare to those of polymerases made of protein, and to what degree its selection in the presence of only $\mathrm{Mg}^{2+}$ and $\mathrm{K}^{+}$has constrained its use of metal ions.

To address these questions, we surveyed the metal ion requirements for activity and folding of the ligase. This ribozyme has an unusual $\mathrm{Mg}^{2+}$ specificity for activity and was inhibited by all other cations tested. However, the ligase can achieve its native, global structure in the presence of several different cations, as determined by hydroxyl radical mapping. That the structure observed by this technique is similar to the active conformation was demonstrated by prefolding the ribozyme in $\mathrm{Ca}^{2+}$ and initiating the reaction with the addition of $\mathrm{Mg}^{2+}$ and EGTA, thus changing the ratelimiting step from folding to catalysis. The rate, $800 \mathrm{~min}^{-1}$ at $\mathrm{pH} 9.0$ and $60 \mathrm{mM} \mathrm{Mg}^{2+}$, is one of the fastest rates yet observed for ribozyme catalysis.

\section{MATERIALS AND METHODS}

RNA Preparation. The class I ligase ribozyme (b1-207, Genbank \#U26413) was transcribed in vitro from a plasmid template linearized with EarI and gel purified on a $6 \%$ denaturing polyacrylamide gel (23). The substrate was an RNA-DNA hybrid (5'-aaaCCAGUC; DNA bases lowercase) synthesized by standard phosphoramidite chemistry. It was $5^{\prime}$-radiolabeled using $\left[{ }^{32} \mathrm{P}\right] \gamma$-ATP or $\left[{ }^{33} \mathrm{P}\right] \gamma$-ATP and T4 polynucleotide kinase.

Manual Kinetic Assays. Metal salts were the highest purity available. RNA, water, buffer, spermine, and non-transition metal salts were extracted with diphenylthiocarbazone in chloroform to remove contaminating transition metal ions $(6,24)$. Residual chloroform did not affect the reaction rates (data not shown). The ribozyme was renatured in water by heating at $85{ }^{\circ} \mathrm{C}$ for $2 \mathrm{~min}$ and cooling at $22{ }^{\circ} \mathrm{C}$ for $2 \mathrm{~min}$. Reactions were carried out with $2 \mu \mathrm{M}$ ligase ribozyme and $\sim 25 \mathrm{nM}$ substrate in $50 \mathrm{mM}$ MES, $\mathrm{pH} 6.0$, at $22{ }^{\circ} \mathrm{C}$ (or room temperature for incubations $<1 \mathrm{~min}$ ). Reactions were started by adding $\left[{ }^{32} \mathrm{P}\right]$-labeled substrate, buffer, and metal ions simultaneously and stopped by the addition of at least 1 vol $8 \mathrm{M}$ urea and EDTA in excess of the divalent metal. Product and substrate were separated on $20 \%$ denaturing polyacrylamide gels and quantified with a Fujix BAS 2000 phosphorimager.

Rapid-Quench Flow Assays. Ribozyme reactions requiring time points earlier than $5 \mathrm{~s}$ were performed in an RQF-3 rapid-quench flow apparatus (KinTek corporation, Austin, TX). Ribozyme in water was heated to $80^{\circ} \mathrm{C}$ for $2 \mathrm{~min}$, and then incubated at $22{ }^{\circ} \mathrm{C}$ for $2 \mathrm{~min}$. EDTA was added to a concentration of $1 \mathrm{mM}$ to chelate any trace divalent metal contaminants, and radiolabeled substrate was then added. To start the reaction, the ribozyme-substrate complex was mixed with an equal volume of reaction buffer. Final reaction conditions were $1 \mu \mathrm{M}$ ligase ribozyme, $\leq 16 \mathrm{nM}$ substrate, $60 \mathrm{mM} \mathrm{MgCl} 2,200 \mathrm{mM} \mathrm{KCl}, 0.6 \mathrm{mM}$ EDTA, and $50 \mathrm{mM}$ BES (pH 7.0), BES (pH 7.4), EPPS (pH 8.0), EPPS (pH 8.5), or CHES ( $\mathrm{pH} 9.0$ ). Reactions were quenched with 0.5 vol 0.5 M EDTA, and then collected and analyzed by gel electrophoresis and phosphorimaging. Reactions in which $\mathrm{CaCl}_{2}$ was used to prefold the ribozyme-substrate complex were performed as above, except that $\mathrm{CaCl}_{2}(3 \mathrm{mM})$ was added to the ribozyme-substrate complex after addition of substrate, and the reaction buffer was supplemented with 5 mM EGTA. At pH 7.0, rates measured with rapid-quench flow matched previous manual measurements of ligation (23).

Rate Determination. Rates were determined using eq 1

$$
\text { fraction reacted }=F_{\mathrm{a}}\left(1-\mathrm{e}^{-k t}\right)
$$

where $t$ equals time, $k$ is the observed rate of catalysis, and $F_{\mathrm{a}}$ equals the fraction of substrate that reacts in an initial burst. In rapid-quench flow experiments in which conformational interconversion was negligible, reaction data were fit to eq 1 using $F_{\mathrm{a}}=0.7$ to adjust for the fraction of enzyme in an active conformation in $60 \mathrm{mM} \mathrm{MgCl} \mathrm{Mg}_{2}$ (23) (N.H.B. and D.P.B., unpublished data). In all manual kinetic experiments, the rates were not corrected for the amount of ribozyme in the active conformation $\left(F_{\mathrm{a}}=1\right)$, because the inactive fraction may be dependent on the identity and concentration of the metal ions $(2,25)$, and it was important not to discount the misfolded molecules in comparing the relative reaction rates in the presence of various metal ions. To fit the data to a single exponential, only times points in which $\leq 35 \%$ of the substrate had reacted were used.

Hydroxyl Radical Mapping. Structural studies were performed on the ligated product because the ribozyme does not fold properly in the absence of substrate (N.H.B. and D.P.B., unpublished data). $10 \mu \mathrm{M}$ ribozyme and $3 \mu \mathrm{M}\left[{ }^{33} \mathrm{P}\right]-$ labeled substrate were reacted to completion in $10 \mathrm{mM}$ $\mathrm{MgCl}_{2}$ and $50 \mathrm{mM}$ MES, $\mathrm{pH}$ 6.0. The $\mathrm{Mg}^{2+}$ was chelated with EDTA, and the ribozyme was precipitated to remove the EDTA/ $\mathrm{Mg}^{2+}$ complex. After resuspension, the reacted ribozyme was extracted with diphenylthiocarbazone. The product was renatured by heating at $85{ }^{\circ} \mathrm{C}$ for 2 min and cooling at $22{ }^{\circ} \mathrm{C}$ for $2 \mathrm{~min}$. The renatured product (final concentration $=1 \mu \mathrm{M}$ ) was mixed with $20 \mathrm{mM}$ MES, $\mathrm{pH}$ 6.0 and various monovalent and/or divalent metals, then incubated at $22{ }^{\circ} \mathrm{C}$ with $2 \mathrm{mM} \mathrm{NH} \mathrm{Ne}_{4} \mathrm{Fe}(\mathrm{II}) \mathrm{SO}_{4}, 2.2 \mathrm{mM}$ EDTA, and $2 \mathrm{mM}$ ascorbic acid $(26,27)$. After $15 \mathrm{~min}$, the cleavage reaction was quenched with $50 \mathrm{mM}$ thiourea. The cleavage reactions were run on $10 \%$ denaturing polyacrylamide gels and quantified by phosphorimaging. After normalizing for loading differences and the overall amount of cleavage in each lane, "protection factors" were determined by dividing the number of counts of a nucleotide in the unfolded ribozyme $\left(0 \mathrm{mM} \mathrm{Mg}^{2+}\right.$ at $\left.60^{\circ} \mathrm{C}\right)$ by the number of counts of that nucleotide in the "folded" ribozyme (various metal concentrations at $\left.22{ }^{\circ} \mathrm{C}\right)(26)$. Except for nucleotide C68, the spectrum of protected residues observed in the renatured product was identical to that seen in previous experiments in which the product was not precipitated and renatured, but was mapped immediately after ligation $(\mathrm{N}$. H. Bergman, N. Lau, V. Lehnert, E. Westhof, and D. P. Bartel, manuscript in preparation).

As a standard for complete folding, each experiment included the ribozyme folded in $10 \mathrm{mM} \mathrm{MgCl}_{2}(\mathrm{~N}$. $\mathrm{H}$. Bergman, N. Lau, V. Lehnert, E. Westhof, and D. P. Bartel, manuscript in preparation). The magnitude of the protection factors for ribozymes folded in $10 \mathrm{mM} \mathrm{MgCl}_{2}$ varied in different experiments, due to differences in the overall degree of cleavage and to differences in the amount of signal over the background radiation of the exposed gels. To compare experiments performed on different days and run on different 

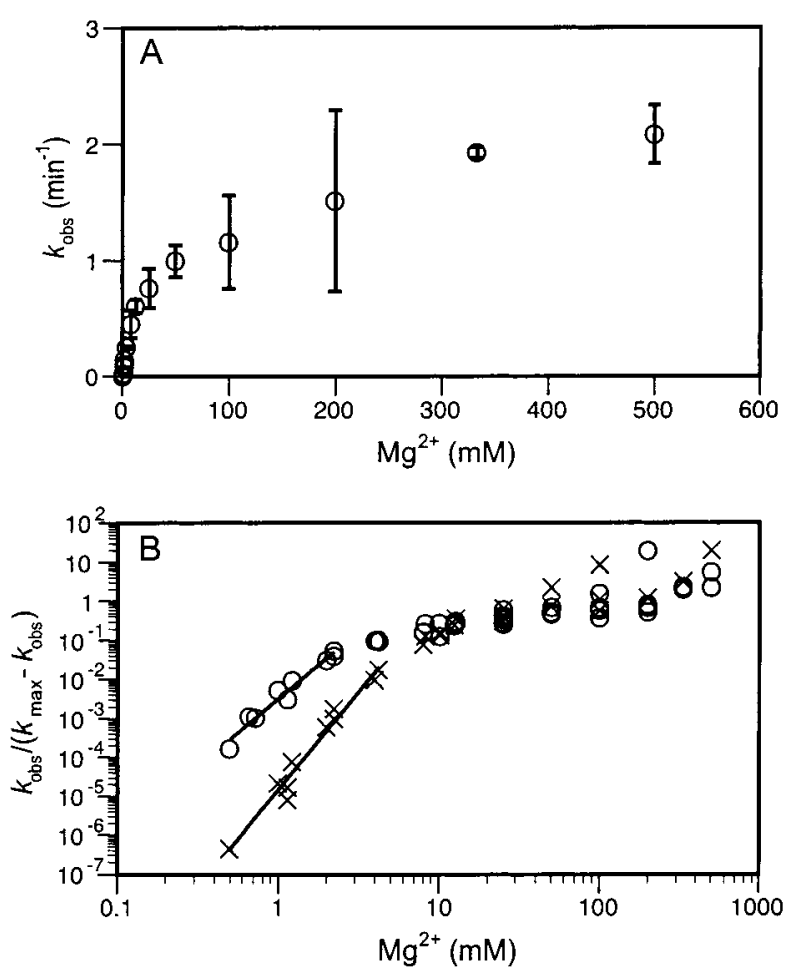

Figure 2: Dependence of activity on $\mathrm{Mg}^{2+}$ at $\mathrm{pH}$ 6.0. (A) The $\mathrm{Mg}^{2+}$ optimum is very high $\left(K_{1 / 2}=70-100 \mathrm{mM}\right)$. (B) Hill analysis demonstrates that the ligase is inhibited by $\mathrm{K}^{+}$at low $\mathrm{Mg}^{2+}$ concentrations. In the absence of $\mathrm{K}^{+}(\mathrm{O})$, the Hill coefficient is 3.5 for $\mathrm{Mg}^{2+}$ concentrations between 0.5 and $2 \mathrm{mM}$ and is $\sim 1$ at $\mathrm{Mg}^{2+}$ concentrations above $8 \mathrm{mM}$. In the presence of $200 \mathrm{mM} \mathrm{KCl}$ $(x)$, the Hill coefficient is 5.0 for $\mathrm{Mg}^{2+}$ concentrations between 0.5 and $4 \mathrm{mM}$ and is $\sim 1$ at $\mathrm{Mg}^{2+}$ concentrations above $8 \mathrm{mM}$. The $k_{\max }$ was estimated to be $2.8 \mathrm{~min}^{-1}$ from the plateau of the curve (increasing its value 10-fold does not affect the Hill coefficients).

gels, the protection factors of each nucleotide were normalized to the average protection of that nucleotide in $10 \mathrm{mM}$ $\mathrm{MgCl}_{2}$ (the average of four experiments). To assess the global structure of the ligase in the presence of various cations, protection factors of the most protected nucleotides (A46C48 and G71-A74) were averaged.

\section{RESULTS}

Metal Requirements for Activity. To study the metal ion requirements for folding and catalysis of the class I ligase, the single-turnover, self-ligating version (Figure 1) was chosen because it offered a simpler context relative to the polymerase and multiple-turnover derivatives $(23,28)$. Previous experiments established that chemistry is rate-limiting from $\mathrm{pH} 5.7-7.0$ in $60 \mathrm{mM} \mathrm{MgCl} 2$ and $200 \mathrm{mM} \mathrm{KCl}$, but the kinetic analysis was not extended to higher $\mathrm{pH}$ because the rates could not be accurately measured by manual pipetting (23). In addition, no other ionic conditions have been explored. We therefore began this study by determining the metal ion requirements of the ligase at $\mathrm{pH}$ 6.0.

Varying the concentration of $\mathrm{Mg}^{2+}$ revealed a high optimum ( $>200 \mathrm{mM}$; Figure 2A). The observed rate is dependent on $\mathrm{pH}$ even at very low $\mathrm{Mg}^{2+}$ concentrations (loglinear dependence, slope $\sim 1$ ), so chemistry appears to be rate-limiting throughout the range of concentrations tested (data not shown). In the absence of $\mathrm{K}^{+}$, the Hill coefficient between 0.5 and $2 \mathrm{mM} \mathrm{Mg}^{2+}$ is 3.5 ; at higher concentrations, the Hill coefficient decreases to $\sim 1$ (Figure 2B). While this decrease may be due to inhibition by high $\mathrm{Mg}^{2+}$ concentrations, it is probably partially or wholly due to the saturation of some $\mathrm{Mg}^{2+}$ binding sites (29). At very low $\mathrm{Mg}^{2+}$ concentrations, the Hill coefficient approaches the minimal number of ligands required for activity. The nonintegral value of the Hill coefficient indicates either that some sites are becoming saturated at the lowest $\mathrm{Mg}^{2+}$ concentration tested or that not all binding sites must be filled for the ligase to achieve some level of activity (29).

Because all previous kinetic analysis of the ligase was performed in the presence of $200 \mathrm{mM} \mathrm{KCl}$, its $\mathrm{Mg}^{2+}$ dependence was also assayed in the presence of $\mathrm{K}^{+}$. Above $8 \mathrm{mM} \mathrm{Mg}^{2+}, \mathrm{K}^{+}$does not alter the Hill coefficient significantly; however, $\mathrm{K}^{+}$inhibits the ribozyme at low $\mathrm{Mg}^{2+}$ concentrations and increases the Hill coefficient to 5.0. ${ }^{2}$ While it is possible that $\mathrm{K}^{+}$somehow increases the number of absolutely required binding sites, another explanation is that in the absence of $\mathrm{K}^{+}$there are also 5 (or more) required $\mathrm{Mg}^{2+}$ binding sites that would only be revealed by Hill analysis at $\mathrm{Mg}^{2+}$ concentrations below $0.5 \mathrm{mM}$. K ${ }^{+}$may compete with one or more $\mathrm{Mg}^{2+}$ (by binding overlapping or nonoverlapping sites), increasing their apparent dissociation constant(s) such that these sites are not saturated at the $\mathrm{Mg}^{2+}$ concentrations tested $(0.5-4 \mathrm{mM})$, and the Hill coefficient is higher. Thus, the ligase requires at least five $\mathrm{Mg}^{2+}$ ions for optimal activity, most of which have high affinities $\left(K_{\mathrm{d}}\right.$ $<2 \mathrm{mM}$ ). At $\left[\mathrm{Mg}^{2+}\right]_{1 / 2}$ the Hill coefficient is $\sim 1$, suggesting that there is a single low-affinity $\mathrm{Mg}^{2+}$ binding site with a $K_{\mathrm{d}}$ near $\left[\mathrm{Mg}^{2+}\right]_{1 / 2}, 70-100 \mathrm{mM}$ (assuming that there is no inhibition by high $\mathrm{Mg}^{2+}$ concentrations).

We next surveyed the activity of the ligase in the presence of other cations. No activity was detected in $\mathrm{Ca}^{2+}, \mathrm{Sr}^{2+}, \mathrm{Ba}^{2+}$, $\mathrm{Zn}^{2+}, \mathrm{Co}^{2+}, \mathrm{Cd}^{2+}, \mathrm{Pb}^{2+}, \mathrm{Co}\left(\mathrm{NH}_{3}\right)_{6}{ }^{3+}$, or spermine (limits of detection, $1 \times 10^{-5} \mathrm{~min}^{-1}$ for $\mathrm{Ca}^{2+}$ and $1 \times 10^{-6} \mathrm{~min}^{-1}$ for the rest), and only marginal activity was detected in $\mathrm{Mn}^{2+}$ (Figure 3). $\mathrm{Mn}^{2+}$ and $\mathrm{Mg}^{2+}$ have similar sizes and coordination geometries, and most natural ribozymes, as well as RNA and DNA polymerases, are very active when $\mathrm{Mn}^{2+}$ is substituted for $\mathrm{Mg}^{2+}(1-6,8,9,30)$. In contrast, the activity of the ligase is orders of magnitude lower in the presence of $\mathrm{Mn}^{2+}$. At the optimal $\mathrm{Mn}^{2+}$ concentration $(2 \mathrm{mM})$, the observed rate was 50-fold less than in $2 \mathrm{mM} \mathrm{Mg}^{2+}$ and 1500 fold less than at the optimal $\mathrm{Mg}^{2+}$ concentration. The activity decreased at higher $\mathrm{Mn}^{2+}$ concentrations, and was undetectable above $20 \mathrm{mM}$. For the hammerhead and an acyl transferase ribozyme, a decrease in activity at high $\mathrm{Mn}^{2+}$ concentrations was attributed to the formation of insoluble

2 These Hill coefficients were interpreted assuming that the ratelimiting step does not change at low $\mathrm{Mg}^{2+}(<10 \mathrm{mM})$ in the presence of additional cations $\left(\mathrm{K}^{+}, \mathrm{Ca}^{2+}\right.$, or $\left.\mathrm{Co}\left(\mathrm{NH}_{3}\right)_{6}{ }^{3+}\right)$. This assumption that the rate of folding (or another step preceding chemistry) does not make a significant contribution to the observed rate can be justified as follows. The rate of folding $\left(k_{\text {fold }}\right)$ is $60 \mathrm{~min}^{-1}$ at $60 \mathrm{mM} \mathrm{Mg}^{2+}$ and $200 \mathrm{mM} \mathrm{K}^{+}$ and is independent of $\mathrm{pH}$ from $\mathrm{pH}$ 7.0-9.0 (discussed later). At 0.5 $\mathrm{mM} \mathrm{Mg}{ }^{2+}$ and $\mathrm{pH} 6.0$, the lower limit for the rate of folding is $2 \mathrm{~min}^{-1}$, based on the $\mathrm{pH}$ dependence of activity at $0.5 \mathrm{mM} \mathrm{Mg}^{2+}$ (data not shown), and the upper limit is at least $60 \mathrm{~min}^{-1}$, if folding is independent of $\mathrm{pH}$ and $\mathrm{Mg}^{2+}$ concentration. For folding to have an effect on the observed rate in the presence of $\mathrm{Mg}^{2+}$ plus $\mathrm{K}^{+}, \mathrm{Ca}^{2+}$, or $\mathrm{Co}\left(\mathrm{NH}_{3}\right)_{6}{ }^{3+}$, the rate of folding would have to decrease by at least 1000-fold at the lowest $\mathrm{Mg}^{2+}$ concentration tested. While such a large decrease is not inconceivable, it would be surprising given that the ribozyme is wellfolded at low concentrations $\left(\left[\mathrm{M}^{2+}\right]_{1 / 2}^{\text {fold }} \leq 1 \mathrm{mM}\right)$ of $\mathrm{Mg}^{2+}$ (in the presence or absence of $\left.\mathrm{K}^{+}\right), \mathrm{Ca}^{2+}$, or $\mathrm{Co}\left(\mathrm{NH}_{3}\right)_{6}{ }^{3+}$, as discussed later. 


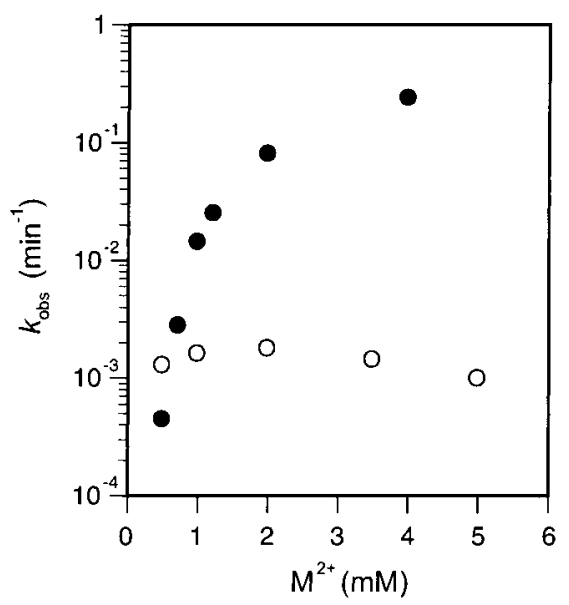

FIGURE 3: Very low ligase activity in $\mathrm{Mn}^{2+}(\mathrm{O})$ compared to $\mathrm{Mg}^{2+}$ (๑). Reactions were at $\mathrm{pH}$ 6.0.

Table 1: Relative Reaction Rates in the Presence of Inhibitory Divalent Cations

\begin{tabular}{lccc}
\hline & \multicolumn{3}{c}{ relative rate $^{a}$} \\
\cline { 2 - 4 } & $0.1 \mathrm{mM} \mathrm{M}^{2+}$ & $1 \mathrm{mM} \mathrm{M}^{2+}$ & $10 \mathrm{mM} \mathrm{M}^{2+}$ \\
\hline $\mathrm{Mn}^{2+}$ & n.d. & 0.56 & 0.032 \\
$\mathrm{Ca}^{2+}$ & n.d. & 0.63 & 0.006 \\
$\mathrm{Sr}^{2+}$ & n.d. & 0.95 & 0.116 \\
$\mathrm{Ba}^{2+}$ & n.d. & 0.81 & 0.046 \\
$\mathrm{Zn}^{2+}$ & 0.59 & 0.007 & $<0.0006$ \\
$\mathrm{Co}^{2+}$ & 0.53 & 0.0009 & $<0.0006$ \\
$\mathrm{Cd}^{2+}$ & 0.09 & $<0.0006$ & $<0.0006$ \\
$\mathrm{~Pb}^{2+}$ & 0.11 & $<0.0006$ & n.d. \\
\hline
\end{tabular}

${ }^{a}$ Reactions were performed under standard conditions in $4 \mathrm{mM}$ $\mathrm{MgCl}_{2}$ plus $0.1,1$, or $10 \mathrm{mM}$ additional divalent ion, and rates are reported relative to the reaction rate in $4 \mathrm{mM} \mathrm{MgCl}_{2}$ only $\left(0.25 \mathrm{~min}^{-1}\right)$. ${ }^{b}$ n.d., not determined.

metal hydroxides at $\mathrm{pH} \geq 8.0(17,31)$. However, this is unlikely at $\mathrm{pH} 6.0(31,32)$. If the affinity of $\mathrm{Mn}^{2+}$ were merely lower than the affinity of $\mathrm{Mg}^{2+}$ for required metal ion binding sites, the activity of the ligase would plateau at a higher metal ion concentration. Because the activity decreases with increasing $\mathrm{Mn}^{2+}$ concentration, it is more probable that $\mathrm{Mn}^{2+}$ binds to inhibitory sites, possibly perturbing the active structure by coordinating to the nitrogens of the bases (33).

Inhibition by Divalent Metals. Although the ligase achieves full activity only in the presence of $\mathrm{Mg}^{2+}$, it is possible that other cations can successfully fill certain sites. In the reactions of RNase $\mathrm{P}$ and the group I intron, cations that do not promote activity on their own can reduce the amount of $\mathrm{Mg}^{2+}$ required for catalysis, providing evidence for different classes of metal ion binding sites $(2,5)$. To explore whether this is true for the ligase, it was assayed in the presence of $4 \mathrm{mM} \mathrm{MgCl}_{2}$ and $0,0.1,1$, or $10 \mathrm{mM}$ additional cation (Table 1). Every divalent metal ion tested was found to inhibit the ligase. The transition metals $\mathrm{Zn}^{2+}, \mathrm{Co}^{2+}, \mathrm{Cd}^{2+}$, and $\mathrm{Pb}^{2+}$ were particularly potent, substantially inhibiting the ligase at micromolar concentrations. This effect was not due to degradation of the ribozyme- only $\mathrm{Pb}^{2+}$ at high concentrations $(10 \mathrm{mM})$ cleaved the ribozyme noticeably (data not shown). The alkaline earth metals were less effective inhibitors, with $\mathrm{Ca}^{2+}$ being more potent than $\mathrm{Sr}^{2+}$ and $\mathrm{Ba}^{2+}$, which have larger radii. Despite having low levels of activity in the presence of $\mathrm{Mn}^{2+}$, the ligase was inhibited quite effectively by this cation. Experiments at other $\mathrm{Mg}^{2+}$ concentrations failed to reveal that any other cation, including those in Table 1 as well as $\mathrm{K}^{+}, \mathrm{Co}\left(\mathrm{NH}_{3}\right)_{6}{ }^{3+}$, and spermine could stimulate the activity of the ligase (data not shown). Thus, only $\mathrm{Mg}^{2+}$ can fulfill all the catalytic and structural requirements of the ligase, but determining if a subset of the required metal ion binding sites are more tolerant required another approach.

If cations other than $\mathrm{Mg}^{2+}$ can successfully fill some of the metal ion binding sites, it may be reflected in the Hill coefficient when both $\mathrm{Mg}^{2+}$ and another cation are present. ${ }^{2}$ Competitive inhibition should increase the apparent dissociation constants, shifting the curve to higher $\mathrm{Mg}^{2+}$ concentrations, while appropriate binding by the other cation should decrease the Hill coefficient at low $\mathrm{Mg}^{2+}$ concentrations where these sites are visible. A decrease in the Hill coefficient, however, cannot establish the number of sites productively bound by the competing cation, because the other cation may not bind the same sites as $\mathrm{Mg}^{2+}$ (34). $\mathrm{Co}\left(\mathrm{NH}_{3}\right)_{6}{ }^{3+}, \mathrm{Ca}^{2+}$, and $\mathrm{Mn}^{2+}$ disrupt $\mathrm{Mg}^{2+}$ binding to at least the lowest affinity site, raising $\left[\mathrm{Mg}^{2+}\right]_{1 / 2}$ to $\sim 200 \mathrm{mM}$ (Figure 4A,B, data not shown). Below $4 \mathrm{mM} \mathrm{Mg}^{2+}$, the Hill coefficient is 3.1 in $60 \mu \mathrm{M} \mathrm{Co}\left(\mathrm{NH}_{3}\right)_{6}{ }^{3+}$, compared to 3.5 in $\mathrm{Mg}^{2+}$ alone or 5.0 in $\mathrm{Mg}^{2+}$ plus $200 \mathrm{mM} \mathrm{K}{ }^{+}$. If activity is completely cooperative (i.e., all metal ion binding sites must be filled to observe any activity), at least 2 of the $\geq 5$ required sites are saturated below $4 \mathrm{mM} \mathrm{Mg}^{2+}$ in the presence or absence of $\mathrm{Co}\left(\mathrm{NH}_{3}\right)_{6}{ }^{3+}$. Unless $\mathrm{Co}\left(\mathrm{NH}_{3}\right)_{6}{ }^{3+}$ has no affinity for these saturated sites, it must be able to fill them (or other functionally equivalent sites) without inhibiting the ribozyme. However, if the ribozyme is active even when not all sites are filled (i.e., activity is partially cooperative or noncooperative), this result provides no information about whether $\mathrm{Co}\left(\mathrm{NH}_{3}\right)_{6}{ }^{3+}$ can productively fill any of the metal ion binding sites. It may merely inhibit the ribozyme.

In contrast, the Hill coefficient between 1 and $10 \mathrm{mM}$ $\mathrm{Mg}^{2+}$ is 2.0 in the presence of $5 \mathrm{mM} \mathrm{Ca}^{2+}$ (Figure 4B). If activity is completely cooperative, fewer $\mathrm{Mg}^{2+}$ are required in the presence of $\mathrm{Ca}^{2+}$ than in its absence, indicating that $\mathrm{Ca}^{2+}$ can replace $\mathrm{Mg}^{2+}$ at some sites (or at other functionally equivalent sites). If activity is not completely cooperative, the lower Hill coefficient in the presence of $\mathrm{Ca}^{2+}$ indicates that there are a higher proportion of ribozymes incompletely bound by $\mathrm{Mg}^{2+}$ contributing to activity. Thus, in either case, binding by $\mathrm{Ca}^{2+}$ reduces the number of $\mathrm{Mg}^{2+}$ required for activity.

The role of $\mathrm{Co}\left(\mathrm{NH}_{3}\right)_{6}{ }^{3+}$ and $\mathrm{Ca}^{2+}$ was also addressed by varying the inhibitor at constant $\mathrm{Mg}^{2+}$ concentration (Figure 4C,D). In this alternative Hill plot, the reaction rate in the presence of inhibitor is compared to the rate in its absence, rather than to the maximum rate. The data fit a curve with a limiting slope at high inhibitor concentrations equal to the number of inhibitor binding sites (29). At $10 \mathrm{mM} \mathrm{Mg}^{2+}$, the Hill coefficient for inhibition approaches 2.2 for $\mathrm{Co}\left(\mathrm{NH}_{3}\right)_{6}{ }^{3+}$ and 1.9 for $\mathrm{Ca}^{2+}$. This number probably approaches the actual number of inhibitory binding sites of $\mathrm{Ca}^{2+}$, because the extent of inhibition is large (97.4-99.8\%). The extent of inhibition by $\mathrm{Co}\left(\mathrm{NH}_{3}\right)_{6}{ }^{3+}(60.2-94.5 \%)$, however, may be insufficient to definitively conclude that there are only two inhibitory binding sites. The results of the two Hill analyses suggest that $\mathrm{Ca}^{2+}$ has two inhibitory binding sites but is able to productively fill some sites required for activity. $\mathrm{Co}\left(\mathrm{NH}_{3}\right)_{6}{ }^{3+}$ 

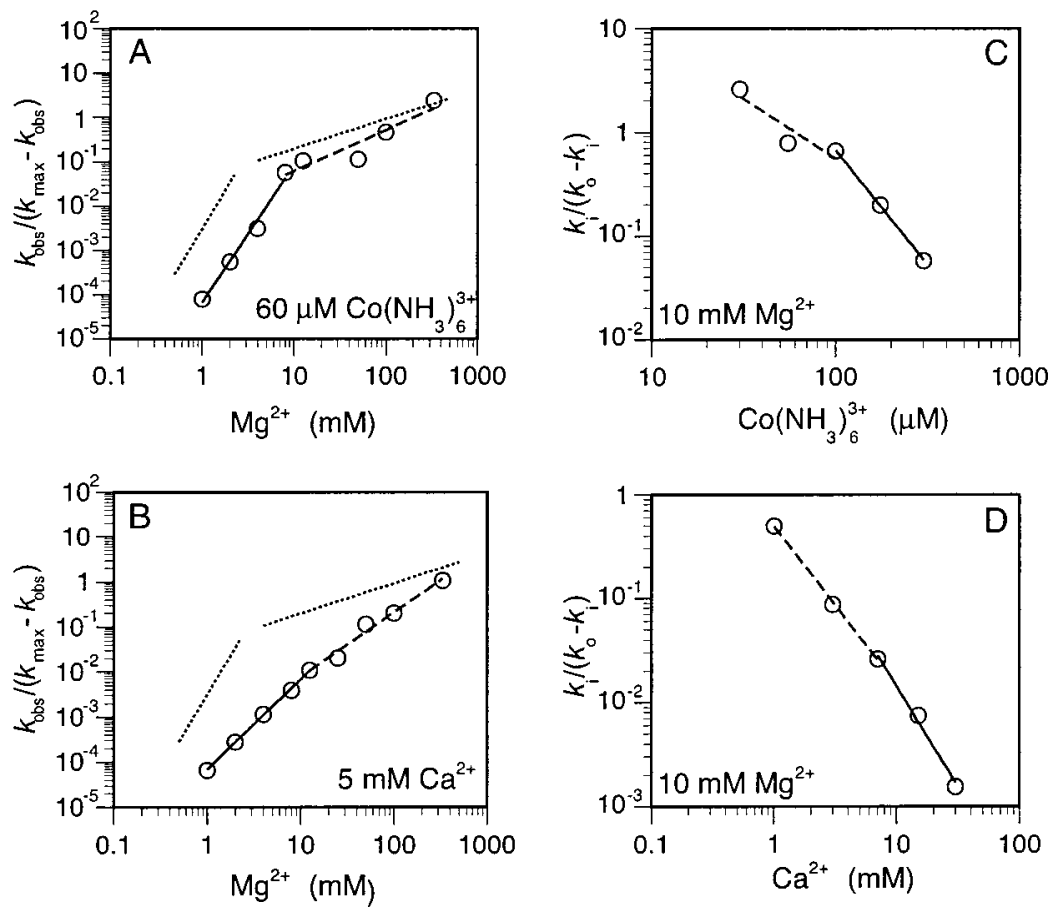

FIGURE 4: Hill analysis in the presence of the indicated inhibitory metals. (A,B) Conventional Hill plots in which the concentration of $\mathrm{Mg}^{2+}$ was varied and $k_{\max }=2.8 \mathrm{~min}^{-1}$. The slope decreases with increasing $\mathrm{Mg}^{2+}$, and the Hill coefficient is given as a range calculated from lines fit to data from lower (solid line) or higher (dashed line) $\mathrm{Mg}^{2+}$ concentrations. Data for $\mathrm{Mg}^{2+}$ alone is shown with a dotted line for comparison. (A) In the presence of $60 \mu \mathrm{M} \mathrm{Co}\left(\mathrm{NH}_{3}\right)_{6} \mathrm{Cl}_{3}$, the Hill coefficient ranges from 3.1 to 0.9 . (B) In the presence of $5 \mathrm{mM} \mathrm{CaCl} 2$, the Hill coefficient ranges from 2.0 to 1.4. (C, D) Hill analysis in which the concentration of $\mathrm{Mg}^{2+}$ was constant and the inhibitor concentration was varied. The rate of the reaction in $10 \mathrm{mM} \mathrm{MgCl}_{2}$ in the absence of inhibitor, $k_{\mathrm{o}}$, is equal to $0.6 \mathrm{~min}^{-1}$, and $k_{\mathrm{i}}$ is the rate of the reaction in $10 \mathrm{mM} \mathrm{MgCl}$ plus the indicated concentration of inhibitor. The slope approaches the number of inhibitory cations bound (29). (C) Varying $\mathrm{Co}\left(\mathrm{NH}_{3}\right)_{6} \mathrm{Cl}_{3}$ concentration results in a limiting slope (solid line) of -2.2. (D) Varying $\mathrm{CaCl}_{2}$ concentration results in a limiting slope (solid line) of -1.9 .

may have more than two inhibitory binding sites, but whether it can fill any required sites is inconclusive.

Structural Metal Ion Requirements. To investigate whether cations other than $\mathrm{Mg}^{2+}$ can fill structural metal ion binding sites, we performed hydroxyl-radical mapping on the ligated product in the presence of various cations (Figure 5). This technique probes the global structure of nucleic acid molecules by preferentially cleaving solvent-accessible residues near the surface of a folded molecule $(35,36)$. In the absence of $\mathrm{Mg}^{2+}, 200 \mathrm{mM} \mathrm{K}{ }^{+}$causes little, if any, of the native structure to form, while protection from cleavage decreases at $1 \mathrm{mM} \mathrm{Mg}^{2+}$ if $200 \mathrm{mM} \mathrm{K}^{+}$is also present (Figure 5B). It is not clear whether this decrease is significant; if so, this result would correspond with the effect of $\mathrm{K}^{+}$on catalysis, in which the inhibition by $\mathrm{K}^{+}$at low $\mathrm{Mg}^{2+}$ concentrations would result in structural destabilization. At higher levels of $\mathrm{Mg}^{2+}, \mathrm{K}^{+}$makes little difference in the global structure of the ribozyme. Clearly, $\mathrm{K}^{+}$does not stabilize the structure or reduce the concentration of $\mathrm{Mg}^{2+}$ required for folding.

In the presence of $\mathrm{Ca}^{2+}$ alone, the ligase achieves the same global structure as in $\mathrm{Mg}^{2+}$ (Figure 5C). Not only is the pattern of protection the same (except C68, which is not reproducibly protected in $\mathrm{Mg}^{2+}$ ), but the concentration of metal ions required for folding is similar- $\left[\mathrm{M}^{2+}\right]_{1 / 2}^{\text {fold }}$ for both metal ions is $\leq 1 \mathrm{mM}$ (Figure 5D; unpublished results). The low metal ion concentration required for folding is in sharp contrast to the high concentration of $\mathrm{Mg}^{2+}$ optimal for catalysis. Apparently, the structural metal ion binding sites have a high affinity for divalent cations and can accommodate $\mathrm{Ca}^{2+}$ as well as $\mathrm{Mg}^{2+}$.
$\mathrm{Co}\left(\mathrm{NH}_{3}\right)_{6}{ }^{3+}$ can also fold the ligase into a nativelike structure (Figure 5E). Much lower concentrations are required; $\left[\mathrm{Co}\left(\mathrm{NH}_{3}\right)_{6}{ }^{3+}\right]_{1 / 2}^{\text {fold }}$ is between 10 and $30 \mu \mathrm{M}$. That a $\sim 40$-fold higher concentration of $\mathrm{Mg}^{2+}$ is required to achieve the same degree of protection was not unexpected due to the stronger electrostatic interaction of the trivalent cobalt complex with the ribozyme $(17,37,38)$. However, the maximum extent of protection is less than that of ribozymes folded in $\mathrm{Mg}^{2+}$, and the level of protection decreases at higher $\mathrm{Co}\left(\mathrm{NH}_{3}\right)_{6}{ }^{3+}$ concentrations. Hill analysis suggested that $\mathrm{Co}\left(\mathrm{NH}_{3}\right)_{6}{ }^{3+}$ may be able to fill fewer required sites than $\mathrm{Ca}^{2+}$ (Figure 4A,B). It is possible that appropriate binding of a couple sites can fold the ribozyme into a nativelike structure, but stable folding requires binding of one or more additional sites, which $\mathrm{Co}\left(\mathrm{NH}_{3}\right)_{6}{ }^{3+}$ cannot bind. Alternatively, $\mathrm{Co}\left(\mathrm{NH}_{3}\right)_{6}{ }^{3+}$ may bind to low-affinity sites in a manner that disrupts the structure.

Kinetics of the Ribozyme Prefolded in $\mathrm{Ca}^{2+}$. The conclusion from hydroxyl-radical mapping studies is that $\mathrm{Ca}^{2+}$ and $\mathrm{Co}\left(\mathrm{NH}_{3}\right)_{6}{ }^{3+}$ can play structural roles in the ligase, even though they inhibit catalysis. A caveat to this conclusion is that these studies were performed on the product of the reaction, which may not be in the active conformation. In addition, hydroxyl-radical mapping is a low-resolution technique. Even though the structures folded by $\mathrm{Mg}^{2+}, \mathrm{Ca}^{2+}$, and $\mathrm{Co}\left(\mathrm{NH}_{3}\right)_{6}{ }^{3+}$ are globally similar, there may be differences in the fine details. To determine whether the structure achieved by the ligase in the presence of $\mathrm{Ca}^{2+}$ is the active one or at least a productive intermediate, we examined the 
A

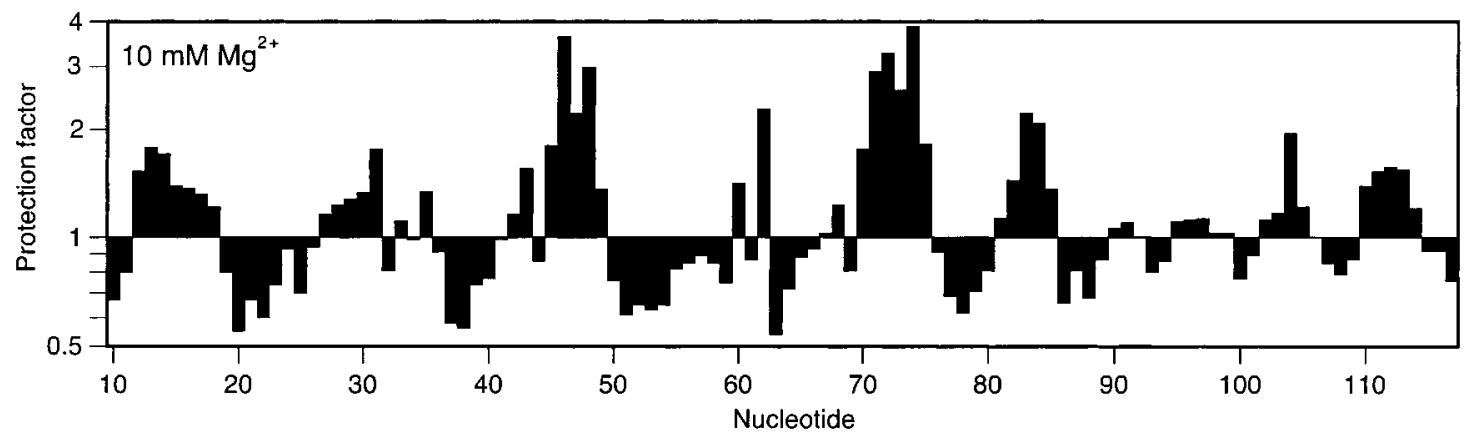

B

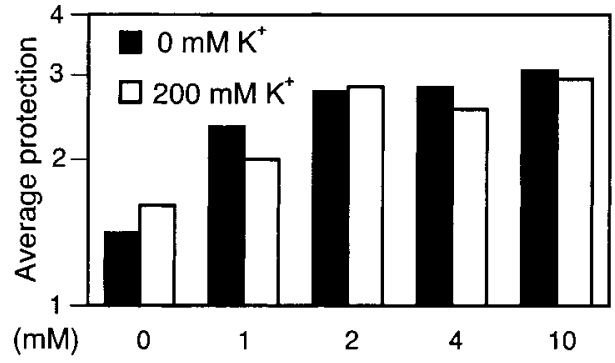

C

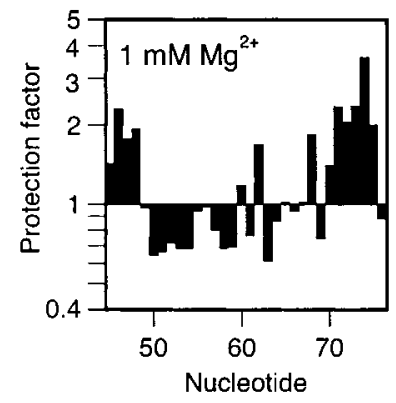

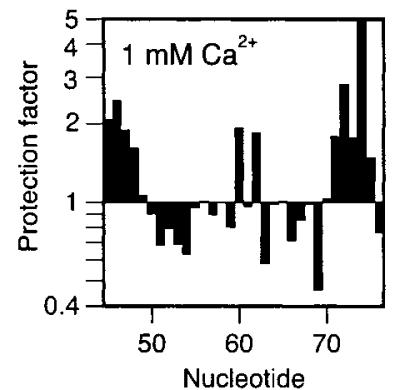

Nucleotide
D

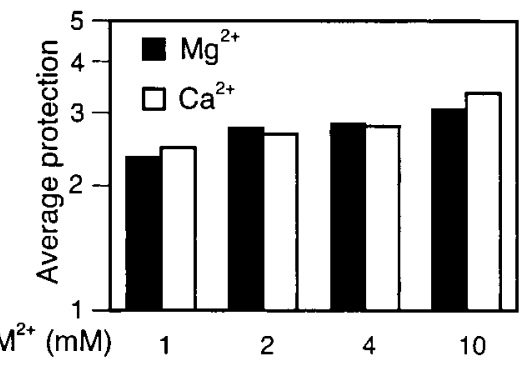

$\mathbf{E}$

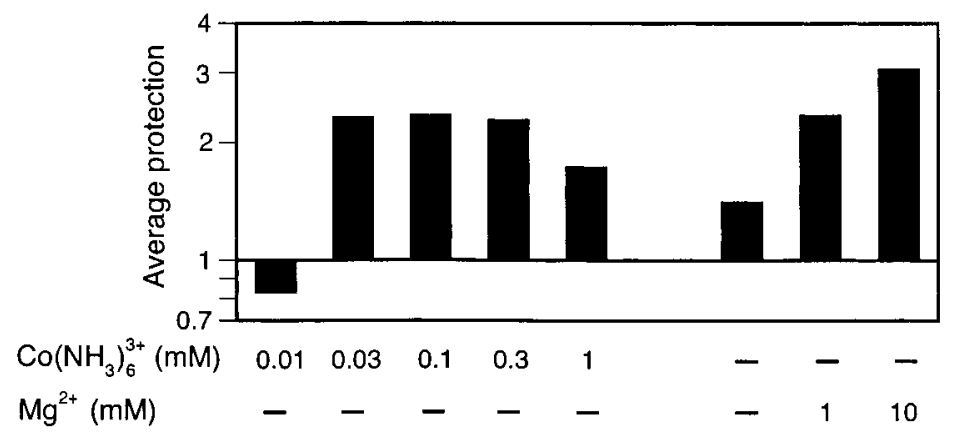

FIGURE 5: Hydroxyl-radical mapping of the class I ligase in the presence of different metal ions. Protection factors are relative to cleavage in the absence of metals at $60^{\circ} \mathrm{C}$. The average protection is the average of the protection factors of the most protected residues (A46-C48, G71-A74). (A) Pattern of protection in $10 \mathrm{mM} \mathrm{MgCl}, 22{ }^{\circ} \mathrm{C}$ (average of four experiments). (B) Comparison of $\mathrm{Mg}^{2+}$-dependent folding in the absence (black) or presence (white) of $200 \mathrm{mM} \mathrm{KCl}$. (C) Protection by low concentrations of $\mathrm{MgCl}_{2}$ or $\mathrm{CaCl}_{2}$. Only the region between nucleotides 45 and 76 is shown. (D) Comparison of folding in the presence of either $\mathrm{MgCl}_{2}$ (black) or CaCl 2 (white). (E) Comparison of folding in $\mathrm{Mg}^{2+}$ or $\mathrm{Co}\left(\mathrm{NH}_{3}\right)_{6}{ }^{3+}$.

kinetics of self-ligation reactions in which the ribozyme was preincubated with $\mathrm{Ca}^{2+}$ (Figure 6A).

In the absence of $\mathrm{Ca}^{2+}$ preincubation, chemistry is ratelimiting and increases with increasing $\mathrm{pH}$ in a log-linear manner from $\mathrm{pH} 5.5$ to $\mathrm{pH} 7.0$ (23). At $\mathrm{pH} \geq 8.0$ the rate plateaus at $60 \mathrm{~min}^{-1}$, indicating that another step in the reaction, presumably folding, becomes rate-limiting above $\mathrm{pH} 7.0$ (Figure 6B, squares). When the ribozyme-substrate complex was preincubated with $\mathrm{Ca}^{2+}$ prior to the addition of $\mathrm{Mg}^{2+}$, the rate was somewhat faster, but not as fast as expected if chemistry were rate-limiting (data not shown). This might be because the ligase is inhibited by $\mathrm{Ca}^{2+}$ or because the ribozyme prefolded with $\mathrm{Ca}^{2+}$ requires a conformation change before chemistry can occur.

To prevent inhibition of the ligation reaction by the $\mathrm{Ca}^{2+}$ used to prefold the ribozyme-substrate complex, the $\mathrm{Mg}^{2+}$ 
A

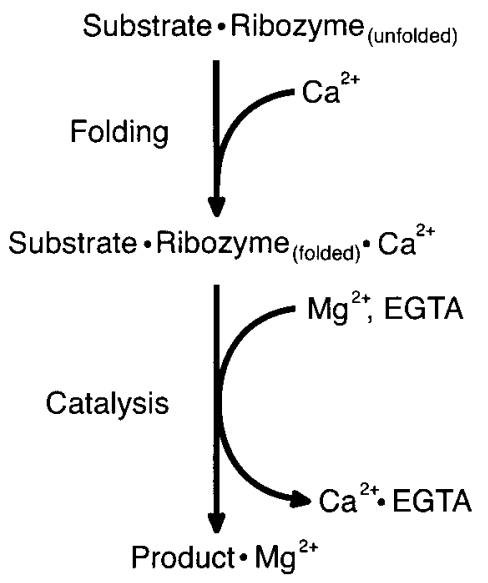

B

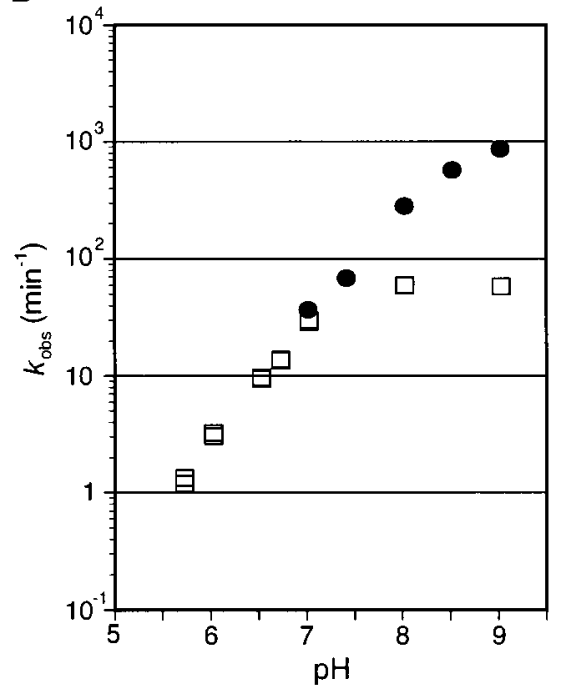

FIGURE 6: Reaction rates of the ligase prefolded in $\mathrm{CaCl}_{2}$. (A) Scheme for prefolding experiment. $\mathrm{Ca}^{2+}$ was added to the renatured substrate-ribozyme complex in water. The reaction was then started by the simultaneous addition of $\mathrm{MgCl}_{2}$ and EGTA. (B) $\mathrm{pH}$ dependence of ligation rates with $(\mathbf{O})$ or without $(\square) \mathrm{CaCl}_{2}$ preincubation. Reactions were in $60 \mathrm{mM} \mathrm{MgCl}_{2}$ and $200 \mathrm{mM} \mathrm{KCl}$.

used to initiate the reaction was supplemented with EGTA, which chelates $\mathrm{Ca}^{2+} 100$ times more readily than $\mathrm{Mg}^{2+}(39)$. When the reaction was started by the simultaneous addition of $\mathrm{Mg}^{2+}$ and EGTA (Figure 6A), ligation rates were loglinear with $\mathrm{pH}$ up to $\mathrm{pH} 8.5$ (slope $=1.0$; Figure $6 \mathrm{~B}$, circles). At $\mathrm{pH}>8.5$, ligation rates rose more slowly with $\mathrm{pH}$, possibly due to deprotonation of the bases and concomitant destabilization of the structure. The ability of $\mathrm{Ca}^{2+}$-preincubation to extend the range in which ligation rates are loglinear with $\mathrm{pH}$ suggests that chemistry is rate-limiting at high $\mathrm{pH}$ for the prefolded ribozyme-substrate complex. Thus, the $\mathrm{Ca}^{2+}$-prefolded ribozyme (and perhaps the product folded in the presence of $\mathrm{Mg}^{2+}, \mathrm{Ca}^{2+}$, or $\mathrm{Co}\left(\mathrm{NH}_{3}\right)_{6}{ }^{3+}$ ) must be very close to the active structure. Any slight, $\mathrm{Mg}^{2+}$-induced conformation changes must be exceedingly fast.

\section{DISCUSSION}

Role of Metal Ions in Structure and Catalysis. The class I ligase, like many other natural ribozymes and ribozymes selected in vitro, has multiple metal ion binding sites with differing roles, affinities, and specificities. Scheme 1 sum-
Scheme 1

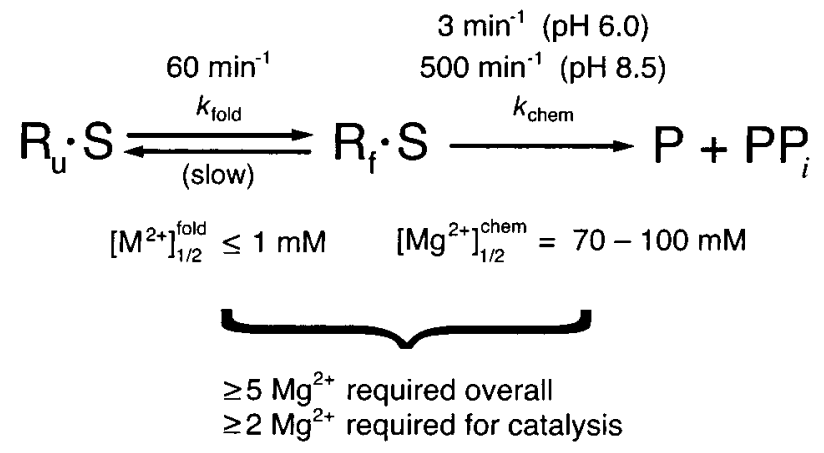

marizes the relationships between metals and ribozyme folding and chemistry (where $\mathrm{R}_{\mathrm{u}}, \mathrm{R}_{\mathrm{f}}, \mathrm{P}, \mathrm{S}$, and $\mathrm{PP}_{\mathrm{i}}$ denote unfolded ribozyme, folded ribozyme, ligated ribozyme, substrate, and pyrophosphate, respectively). Folding of the ribozyme is rapid $\left(60 \mathrm{~min}^{-1}\right)$, but can become rate-limiting at higher $\mathrm{pH}$. Low metal ion concentrations are required for folding, which proceeds equally well in the presence of $\mathrm{Mg}^{2+}$ or $\mathrm{Ca}^{2+}$. In contrast, much higher $\mathrm{Mg}^{2+}$ concentrations are required for catalysis, and only $\mathrm{Mg}^{2+}$ is sufficient for optimal catalysis. Overall, $\geq 5 \mathrm{Mg}^{2+}$ are required for folding and catalysis, and the presence of $\mathrm{Ca}^{2+}$ reduces the number of required $\mathrm{Mg}^{2+}$ to $\geq 2$, suggesting that two metal ions may be required for catalysis.

Scheme 1 was built with several simplifications. Folding is represented as a single step, representing attainment of catalytic competence. In reality, folding is probably several distinct steps, as has been seen for other RNAs (40-43). Furthermore, Scheme 1 begins with substrate bound to the ribozyme prior to folding and disregards the contribution of $\mathrm{Mg}^{2+}$-dependent folding prior to substrate association. This is justified because at high $\mathrm{pH}$, where folding is rate-limiting, incubation in $\mathrm{Mg}^{2+}$ before adding high concentrations of substrate does not increase the ligation rate (data not shown), suggesting that the ligase does not stably exist in a folded form without bound substrate. Thus, ligation rates largely reflect reactions in which folding is preceded by substrate association. The rate of unfolding is described as slow because the equilibrium between $R_{u} \cdot S$ and $R_{f} \cdot S$ appears to lie toward the folded form (at least at high $\mathrm{Mg}^{2+}$ concentrations). This is based on the observation that reaction time courses for the $\mathrm{Ca}^{2+}$-preincubation experiments fit a singleexponential curve, even at high $\mathrm{pH}$, as expected for a homogeneous population of molecules that are correctly folded at the moment of $\mathrm{Mg}^{2+}$ addition. The chemical step $\left(\mathrm{R}_{\mathrm{f}} \cdot \mathrm{S} \rightarrow \mathrm{P}+\mathrm{PP}_{\mathrm{i}}\right)$ is represented as irreversible because previous work has shown that the reverse reaction (pyrophosphorolysis with formation of a triphosphate) is $10^{7}$-times slower than the forward reaction (21).

The $\mathrm{Mg}^{2+}$ preference for catalysis is in stark contrast to RNA and DNA polymerases made of protein and most natural ribozymes, which have similar levels of activity in $\mathrm{Mg}^{2+}$ and $\mathrm{Mn}^{2+}(1-6,8,9,30)$. One (or more) low-affinity $\mathrm{Mg}^{2+}$ appears to be required for catalysis; $\left[\mathrm{Mg}^{2+}\right]_{1 / 2}$ for folding is $\leq 1 \mathrm{mM}$, but $\left[\mathrm{Mg}^{2+}\right]_{1 / 2}$ for activity is over $70 \mathrm{mM}$. $\mathrm{Co}\left(\mathrm{NH}_{3}\right)_{6}{ }^{3+}$ and $\mathrm{Ca}^{2+}$ probably compete with $\mathrm{Mg}^{2+}$ for the low-affinity site (or fill nonoverlapping, mutually exclusive sites), both because they can fill some or all high-affinity structural sites and because they increase the apparent $K_{\mathrm{d}}$ of the low-affinity site to $\sim 200 \mathrm{mM}$. Likewise, $\mathrm{Mn}^{2+}$ increases 
the apparent dissociation constant of the low-affinity site, due to suboptimal binding to this site or disruptive binding to inhibitory sites (data not shown).

While it is apparent from kinetic and structural studies that $\mathrm{Mn}^{2+}, \mathrm{Ca}^{2+}$, and $\mathrm{Co}\left(\mathrm{NH}_{3}\right)_{6}{ }^{3+}$ can fill a subset of the required metal ion binding sites, one question that remains is whether they inhibit by binding (or preventing $\mathrm{Mg}^{2+}$ from binding) to structurally or catalytically required sites. $\mathrm{Mn}^{2+}$ must be able to fulfill all of the structural and catalytic requirements to some degree, because the ribozyme is slightly active in the presence of $\mathrm{Mn}^{2+}$ alone. However, if the ribozyme retains some activity even when not all stimulatory sites are bound, it is possible that $\mathrm{Mn}^{2+}$ cannot fill all $\mathrm{Mg}^{2+}$ binding sites. Inhibition by $\mathrm{Mn}^{2+}$ could then be the result of disruptively overlapping some $\mathrm{Mg}^{2+}$ binding sites, in addition to binding other sites with no affinity for $\mathrm{Mg}^{2+}$.

$\mathrm{Co}\left(\mathrm{NH}_{3}\right)_{6}{ }^{3+}$ and $\mathrm{Ca}^{2+}$ must be able to fill some or all structurally required sites, because they both fold the ribozyme into nativelike structures. Hill analysis suggested that $\mathrm{Ca}^{2+}$ may fill more of the required sites than $\mathrm{Co}\left(\mathrm{NH}_{3}\right)_{6}{ }^{3+}$. Coupled to the lesser extent of hydroxyl-radical protection in the presence of $\mathrm{Co}\left(\mathrm{NH}_{3}\right)_{6}{ }^{3+}$ relative to $\mathrm{Mg}^{2+}$ or $\mathrm{Ca}^{2+}$, this suggests that $\mathrm{Co}\left(\mathrm{NH}_{3}\right)_{6}{ }^{3+}$ may not fill all structurally required sites. Nevertheless, the high level of structure formed in the presence of $\mathrm{Co}\left(\mathrm{NH}_{3}\right)_{6}{ }^{3+}$, as well as its competition for the low-affinity, catalytic site suggests that $\mathrm{Co}\left(\mathrm{NH}_{3}\right)_{6}{ }^{3+}$ also competes with $\mathrm{Mg}^{2+}$ for catalytic metal ion binding sites (or binds mutually exclusive sites), rather than merely disrupting the ribozyme fold.

Unless $\mathrm{Ca}^{2+}$ subtly perturbs the structure, it also inhibits by competing for catalytic sites (or mutually exclusive sites). Additional support for this comes from measuring the activity at high $\mathrm{pH}$ after preincubating the ribozyme-substrate complex with $\mathrm{Ca}^{2+}$. Under these conditions, chemistry is ratelimiting up to approximately $\mathrm{pH} 8.5$, so the rate of any conformation changes must significantly exceed $500 \mathrm{~min}^{-1}$, the rate of the chemical step at $\mathrm{pH}$ 8.5. In comparison, tRNA folds 10-fold faster than this, the catalytic domain of RNase $P$ folds at the same rate, the fast steps of group I intron folding proceed 8-fold slower, and large conformational changes of several ribozymes occur on the order of minutes (41, 44-49).

While it is not possible to determine whether the inhibitory ions compete directly with $\mathrm{Mg}^{2+}$ by binding overlapping sites or whether their binding to more distant sites alters the conformation and occludes $\mathrm{Mg}^{2+}$ binding sites, their inability to adequately fill some required sites does suggest that certain chemical attributes of $\mathrm{Mg}^{2+}$ are vital for ribozyme activity. $\mathrm{Ca}^{2+}$, for instance, has a larger radius and a higher $\mathrm{p} K_{\mathrm{a}}$ than $\mathrm{Mg}^{2+}$. Before assessing the importance of these characteristics for ligase activity, it will be useful to discuss the role of $\mathrm{Ca}^{2+}$ in uncatalyzed RNA ligation and in some ribozymecatalyzed reactions.

The uncatalyzed ligation reaction, in which two RNAs aligned by base-pairing to a template are ligated to form a $3^{\prime}, 5^{\prime}$-phosphodiester bond and release pyrophosphate, works with a wide variety of metal ions, and the rate varies inversely with the metal ion's $\mathrm{p} K_{\mathrm{a}}(50)$. The differences between the rates in the presence of different metal ions correlates with the difference between their $\mathrm{p} K_{\mathrm{a}}$ 's, such that the rate with $\mathrm{Mn}^{2+}\left(\mathrm{p} K_{\mathrm{a}}=10.6\right)$ is 6-10-fold higher than with $\mathrm{Mg}^{2+}\left(\mathrm{p} K_{\mathrm{a}}=11.4\right)$, and the rate with $\mathrm{Mg}^{2+}$ is 13 -fold higher than with $\mathrm{Ca}^{2+}\left(\mathrm{p} K_{\mathrm{a}}=12.9\right)$. Likewise, a 2',5' ligase ribozyme, which was selected in vitro and performs a reaction similar to the class I ligase, demonstrates the same relationship between its activity and the $\mathrm{p} K_{\mathrm{a}}$ of the metal ion (51). Most in vitro-selected and natural ribozymes, however, tend to show more complex behavior. The group I ribozyme prefers $\mathrm{Mn}^{2+}$ over $\mathrm{Mg}^{2+}$ in a class of binding sites thought to be required for catalysis, but it is inactive in $\mathrm{Ca}^{2+}(2)$. The 1.5 unit difference between the $\mathrm{p} K_{\mathrm{a}}$ 's of $\mathrm{Mg}^{2+}$ and $\mathrm{Ca}^{2+}$ cannot account for the total inability of $\mathrm{Ca}^{2+}$ to support catalysis. Instead, it was shown that $\mathrm{Mn}^{2+}$ and $\mathrm{Ca}^{2+}$ bind to a site adjacent to the previously identified $\mathrm{Mg}^{2+}$ binding sites. $\mathrm{Mn}^{2+}$ at this site stimulates catalysis, while $\mathrm{Ca}^{2+}$ inhibits the chemical step (34). Likewise, the slightly lower $\mathrm{p} K_{\mathrm{a}}$ of $\mathrm{Ca}^{2+}$ is unlikely to account for its inhibition of the ligase ribozyme. It is more probable that $\mathrm{Ca}^{2+}$ distorts the active site, either because it is too large or it binds to an incorrect site. However, whether $\mathrm{Mn}^{2+}$ is preferred over $\mathrm{Mg}^{2+}$ at the active site is impossible to discern because $\mathrm{Mn}^{2+}$ inhibits the ligase ribozyme by binding to other sites.

In addition to a possible size requirement at certain metal ion binding sites, inhibition by $\mathrm{Co}\left(\mathrm{NH}_{3}\right)_{6}{ }^{3+}$ suggests that innersphere contact is required at some sites, since Co$\left(\mathrm{NH}_{3}\right)_{6}{ }^{3+}$ is exchange-inert and similar in size and shape to a fully hydrated $\mathrm{Mg}^{2+}(10,11,52)$. Because the ribozyme is well-folded by $\mathrm{Ca}^{2+}$ and mostly folded by $\mathrm{Co}\left(\mathrm{NH}_{3}\right)_{6}{ }^{3+}$, it is likely they both disrupt $\mathrm{Mg}^{2+}$ binding to catalytic sites, especially the low-affinity site. The correct positioning of the active site may therefore require binding by at least one metal ion with a radius smaller than that of $\mathrm{Ca}^{2+}$ and innersphere coordination of one or more metal ions.

Mechanism of the Class I Ligase. $\mathrm{Ca}^{2+}$ inhibits the ligase by binding to two sites, yet the ribozyme appears to be correctly folded. This raises the tantalizing possibility that the ligase uses a mechanism requiring two metal ions, similar to that of protein-enzyme polymerases $(22,53-55)$. In this mechanism, one metal ion coordinates the $3^{\prime}-\mathrm{OH}$ of the primer and the pro- $R_{\mathrm{P}}$-oxygen of the $\alpha$-phosphate belonging to the incoming nucleotide (54), and the other contacts the nonbridging oxygens of the triphosphate, all through innersphere coordination $(53-55)$. The first metal ion promotes the attack of the $3^{\prime}-\mathrm{OH}$ on the $\alpha$-phosphate by lowering its affinity for hydrogen, and the second stabilizes the pyrophosphate leaving group (22). This mechanism is common to several nonhomologous polymerases $(22,53-55)$, as well as to enzymes that catalyze other phosphoryl transfer reactions (albeit with differing stereochemical preferences), including the $3^{\prime}-5^{\prime}$ exonuclease of DNA polymerase I and alkaline phosphatase (56-59).

In the reaction catalyzed by the ligase ribozyme, one of the required metal ions is undoubtedly chelated to the triphosphate, with a $K_{\mathrm{d}}$ between 10 and $100 \mu \mathrm{M}$, if binding to the triphosphate is not influenced by additional interactions with the ribozyme $(39,50)$. Given that $\mathrm{K}^{+}$has a $K_{\mathrm{d}}$ of $100-$ $300 \mathrm{mM}$ for nucleoside triphosphates (39), the apparent dissociation constant of $\mathrm{Mg}^{2+}$ would be $17-300 \mu \mathrm{M}$ in the presence of $200 \mathrm{mM} \mathrm{KCl}$, assuming competitive inhibition (eq 2).

$$
K_{\mathrm{d}}^{\mathrm{app}}=K_{\mathrm{d}}^{\mathrm{Mg}^{2+}}\left(1+\frac{\left[K^{+}\right]}{K_{\mathrm{d}}^{\mathrm{K}^{+}}}\right)
$$


If the $K_{\mathrm{d}}$ of $\mathrm{Mg}^{2+}$ is at the upper end of this range, competition by $\mathrm{K}^{+}$for this site should be represented in the higher Hill coefficient at low $\mathrm{Mg}^{2+}$ concentrations. A second catalytically required $\mathrm{Mg}^{2+}$ binds the low-affinity site, possibly coordinating the $3^{\prime}-\mathrm{OH}$ and the $\alpha$-phosphate. The dissociation constant of $\mathrm{Mg}^{2+}$ bound to this site is expected to be less than or equal to the $\left[\mathrm{Mg}^{2+}\right]_{1 / 2}$ of the uncatalyzed reaction $(150-300 \mathrm{mM})(50)$. Because the $\left[\mathrm{Mg}^{2+}\right]_{1 / 2}$ is actually $70-100 \mathrm{mM}$, any additional ribozyme contacts may be weak, or the ribozyme may facilitate chemistry by a strategy involving $\mathrm{Mg}^{2+}$ in substrate destabilization (60).

While there is no evidence supporting the specific metal contacts required by the two-metal-ion mechanism for the ligase reaction, there are several parallels between reactions catalyzed by the ligase ribozyme and proteinaceous polymerases that are consistent with this mechanism. The ligase, which forms the catalytic core of an RNA polymerase ribozyme, has the same stereochemical preference for sulfur substitution at the $\alpha$-phosphate as polymerases composed of protein $(20,21)$, and both the ligase and polymerases made of protein can tolerate only $\mathrm{Mg}^{2+}$ or $\mathrm{Mn}^{2+}$ at their active sites (30). In addition, kinetic and structural analysis in the presence of $\mathrm{Mg}^{2+}$ and $\mathrm{Ca}^{2+}$ suggested that the ligase may require two metal ions for catalysis. If this model is correct and the polymerase ribozyme uses the same mechanism as the ligase, the two-metal-ion mechanism may be truly universal for polymerases (22).

The Class I Ligase and the RNA World. The ligase not only performs the chemistry of RNA polymerization, a reaction crucial to the RNA world hypothesis, but it is also one of the fastest ribozymes. Under optimal conditions, selfligation proceeds at a rate of $800 \mathrm{~min}^{-1}$, comparable to that of the RNA component of RNase P (360 $\left.\mathrm{min}^{-1}\right)$ (61), and both ribozymes have rates 10 times faster than the observed rates of most other ribozymes $(17,31,51,62-64)$. However, the optimal conditions for these ribozymes differ from each other and from physiological conditions.

To make a fair comparison to natural ribozymes and evaluate the ligase as a reasonable facsimile of an RNA world enzyme, it would be useful to estimate its level of activity under physiological and possible primordial conditions. The physiological concentration of free $\mathrm{Mg}^{2+}$ is $1-2 \mathrm{mM}$, free $\mathrm{Ca}^{2+}$ is approximately $0.1 \mu \mathrm{M}$, and total monovalent cations are about $200 \mathrm{mM}(33,65-67)$. Ignoring polycations that may inhibit the ribozyme further, the ligase would exhibit only 0.001 of its optimal activity, at best, under these conditions. With a $\mathrm{Mg}^{2+}$ concentration of about $50 \mathrm{mM}$, seawater (a possible primordial environment) may seem more favorable $(33,68)$; however, the high concentration of $\mathrm{Ca}^{2+}$ $(\sim 10 \mathrm{mM})$ would severely inhibit the ligase (33). While it is difficult to compare the ligase to natural ribozymes under physiological conditions, the group I intron and RNase P are considerably more tolerant of $\mathrm{Ca}^{2+}$ at high $\mathrm{Mg}^{2+}$ concentrations $(2,69,70)$, and the small self-cleaving ribozymes are very active in the presence of many cations, including $\mathrm{Ca}^{2+}(6-9)$.

It is not surprising that the ligase is less tolerant of other metals than natural ribozymes, considering that it experienced only $\mathrm{Mg}^{2+}$ and $\mathrm{K}^{+}$during its selection. The question then arises whether it would be worthwhile to perform in vitro selections in a broader range of metal ions. There is no clear trend demonstrating that the metal ion requirements of ribozymes are defined by the metal ions present during their selection. Although selected in the presence of only $\mathrm{Mg}^{2+}$ and $\mathrm{K}^{+}$, like the class I ligase, an acyl transferase and a $2^{\prime}, 5^{\prime}$ RNA ligase are active in a wide variety of metal ions $(17,18,51)$. Other ribozymes selected in a mixture of metal ions are limited to activity in only a few and may be inhibited by some ions $(71-75)$. If lower $\mathrm{Mg}^{2+}$ concentrations and a wider variety of metal ions had been used in the ligase selection, the class I ligase would have been at a severe disadvantage. As it was, this ligase was the only member of its family isolated from a pool of $10^{15}$ sequences (19). Despite the lack of ionic stringency during the selection, a ribozyme as catalytically efficient as many in nature was discovered. Selecting variants of the ligase with lower $\mathrm{Mg}^{2+}$ optima and higher metal tolerance, as demonstrated previously with the group I intron and RNase P $(76,77)$, may lead to the discovery of ribozymes that are active in conditions simulating intracellular or possible prebiotic environments.

\section{ACKNOWLEDGMENT}

We thank Vernon Anderson for providing peroxynitrous acid used in hydroxyl radical mapping and Jamie Cate for helpful discussions. We also thank Alex Kravchuk and Ed Curtis for useful comments on the manuscript.

\section{REFERENCES}

1. Pyle, A. M. (1996) Met. Ions Biol. Syst. 32, 479-520.

2. Grosshans, C. A., and Cech, T. R. (1989) Biochemistry 28, 68886894.

3. Deme, E., Nolte, A., and Jacquier, A. (1999) Biochemistry 38 , 3157-3167.

4. Gardiner, K. J., Marsh, T. L., and Pace, N. R. (1985) J. Biol. Chem. 260, 5415-5419.

5. Guerrier-Takada, C., Haydock, K., Allen, L., and Altman, S. (1986) Biochemistry 25, 1509-1515.

6. Dahm, S. C., and Uhlenbeck, O. C. (1991) Biochemistry 30, 94649469.

7. Chowrira, B. M., Berzal-Herranz, A., and Burke, J. M. (1993) Biochemistry 32, 1088-1095.

8. Collins, R. A., and Olive, J. E. (1993) Biochemistry 32, 27952799.

9. Suh, Y.-A., Kumar, P. K. R., Taira, K., and Nishikawa, S. (1993) Nucleic Acids Res. 21, 3277-3280.

10. Hampel, A., and Cowan, J. A. (1997) Chem. Biol. 4, 513-517.

11. Young, K. J., Gill, F., and Grasby, J. A. (1997) Nucleic Acids Res. 25, 3760-3766.

12. Murray, J. B., Seyhan, A. A., Walter, N. G., Burke, J. M., and Scott, W. G. (1998) Chem. Biol. 5, 587-595.

13. Curtis, E. A., and Bartel, D. P. (2001) RNA 7, 546-552.

14. Pan, T., and Uhlenbeck, O. C. (1992) Biochemistry 31, 38873895.

15. Pan, T., Dichtl, B., and Uhlenbeck, O. C. (1994) Biochemistry $33,9561-9565$.

16. Sugimoto, N., and Ohmichi, T. (1996) FEBS Lett. 393, 97-100.

17. Suga, H., Cowan, J. A., and Szostak, J. W. (1998) Biochemistry 37, 10118-10125.

18. Lohse, P. A., and Szostak, J. W. (1996) Nature 281, 442-444.

19. Ekland, E. H., Szostak, J. W., and Bartel, D. P. (1995) Science $269,364-370$.

20. Johnston, W. K., Unrau, P. J., Lawrence, M. S., Glasner, M. E., and Bartel, D. P. (2001) Science 292, 1319-1325.

21. Glasner, M. E., Yen, C. C., Ekland, E. H., and Bartel, D. P. (2000) Biochemistry 39, 15556-15562.

22. Steitz, T. A. (1998) Nature 391, 231-232.

23. Bergman, N. H., Johnston, W. K., and Bartel, D. P. (2000) Biochemistry 39, 3115-3123.

24. Holmquist, B. (1988) Methods Enzymol. 158, 6-12.

25. Tanner, N. K., and Cech, T. R. (1985) Nucleic Acids Res. 13, $7741-7758$.

26. Pan, T. (1995) Biochemistry 34, 902-909.

27. Celander, D. W., and Cech, T. R. (1991) Science 251, 401-407. 
28. Ekland, E. H., and Bartel, D. P. (1996) Nature 382, 373-376.

29. Segel, I. H. (1975) Enzyme Kinetics, John Wiley and Sons, Inc., New York.

30. Mildvan, A. S., and Loeb, L. A. (1979) CRC Crit. Rev. Biochem. 6, 219-244.

31. Dahm, S. C., Derrick, W. B., and Uhlenbeck, O. C. (1993) Biochemistry 32, 13040-13045.

32. Cotton, F. A., and Wilkinson, G. (1988) Adv. Inorg. Chem., 5th ed., John Wiley and Sons, New York.

33. Pan, T., Long, D. M., and Uhlenbeck, O. C. (1993) in The RNA World (Gesteland, R. F., and Atkins, J. F., Eds.) pp 271-302, Cold Spring Harbor Laboratory Press, Cold Spring Harbor, New York.

34. Shan, S.-O., and Herschlag, D. (2000) RNA 6, 795-813.

35. Tullius, T. D., Dombroski, B. A., Churchill, M. E. A., and Kam, L. (1987) Methods Enzymol. 155, 537-558.

36. Latham, J. A., and Cech, T. R. (1989) Science 245, 276-282.

37. Hampel, K. J., Walter, N. G., and Burke, J. M. (1998) Biochemistry 37, 14672-14682.

38. Nesbitt, S., Hegg, L. A., and Fedor, M. J. (1997) Chem. Biol. 4, 619-630.

39. Dawson, R. M. C., Elliott, D. C., Elliott, W. H., and Jones, K. M. (1986) Data for Biochemical Research, 3rd ed., Clarendon Press, Oxford.

40. Pan, T., and Sosnick, T. R. (1997) Nat. Struct. Biol. 4, 931-938.

41. Sclavi, B., Sullivan, M., Chance, M. R., Brenowitz, M., and Woodson, S. A. (1998) Science 279, 1940-1943.

42. Treiber, D. K., Rook, M. S., Zarrinkar, P. P., and Williamson, J. R. (1998) Science 279, 1943-1946.

43. Crothers, D. M., Cole, P. E., Hilbers, C. W., and Shulman, R. G. (1974) J. Mol. Biol. 87, 63-88.

44. Draper, D. E. (1996) Nat. Struct. Biol. 3, 397-400.

45. Fang, X.-W., Pan, T., and Sosnick, T. R. (1999) Nat. Struct. Biol. 6, 1091-1095.

46. Zhuang, X., Bartley, L. E., Babcock, H. P., Russell, R., Ha, T., Herschlag, D., and Chu, S. (2000) Science 288, 2048-2051.

47. Zarrinkar, P. P., and Williamson, J. R. (1994) Science 265, $918-$ 924.

48. Zarrinkar, P. P., Wang, J., and Williamson, J. R. (1996) RNA 2, $564-573$.

49. Walter, N. G., Hampel, K. J., Brown, K. M., and Burke, J. M. (1998) ЕМBO J. 17, 2378-2391.

50. Rohatgi, R., Bartel, D. P., and Szostak, J. W. (1996) J. Am. Chem. Soc. 118, 3332-3339.

51. Landweber, L. F., and Pokrovskaya, I. D. (1999) Proc. Natl. Acad. Sci. U.S.A. 96, 173-178.

52. Jou, R., and Cowan, J. A. (1991) J. Am. Chem. Soc. 113, 66856686.
53. Pelletier, H., Sawaya, M. R., Kumar, A., Wilson, S. H., and Kraut, J. (1994) Science 264, 1891-1903.

54. Doublie, S., Tabor, S., Long, A. M., Richardson, C. C., and Ellenberger, T. (1998) Nature 391, 251-258.

55. Kiefer, J. R., Mao, C., Braman, J. C., and Beese, L. S. (1998) Nature 391, 304-307.

56. Steitz, T. A., and Steitz, J. A. (1993) Proc. Natl. Acad. Sci. U.S.A. 90, 6498-6502.

57. Freemont, P. S., Friedman, J. M., Beese, L. S., Sanderson, M. R., and Steitz, T. A. (1988) Proc. Natl. Acad. Sci. U.S.A. 85, 89248928.

58. Beese, L. S., and Steitz, T. A. (1991) EMBO J. 10, 25-33.

59. Kim, E. E., and Wyckoff, H. W. (1991) J. Mol. Biol. 218, 449464.

60. Narlikar, G. J., Gopalakrishnan, V., McConnell, T. S., Usman, N., and Herschlag, D. (1995) Proc. Natl. Acad. Sci. U.S.A. 92, 3668-3672.

61. Beebe, J. A., and Fierke, C. A. (1994) Biochemistry 33, 1029410304.

62. Esteban, J. A., Banerjee, A. R., and Burke, J. M. (1997) J. Biol. Chem. 272, 13629-13639.

63. Herschlag, D., and Cech, T. R. (1990) Biochemistry 29, 1015910171.

64. Olive, J. E., and Collins, R. A. (1998) Biochemistry 37, 64766484.

65. Snavely, M. D. (1990) Met. Ions Biol. Syst. 26, 155-175.

66. Maguire, M. E. (1990) Met. Ions Biol. Syst. 26, 135-153.

67. Lodish, H., Baltimore, D., Berk, A., Zipursky, S. L., Matsudaira, P., and Darnell, J. (1995) Molecular Cell Biology, 3rd ed., Scientific American Books, New York.

68. Lahav, N. (1999) Biogenesis: Theories of Life's Origin, Oxford University Press, New York.

69. McConnell, T. S., Herschlag, D., and Cech, T. R. (1997) Biochemistry 36, 8293-8303.

70. Smith, D., and Pace, N. R. (1993) Biochemistry 32, 5273-5281.

71. Seelig, B., and Jaschke, A. (1999) Chem. Biol. 6, 167-176.

72. Illangasekare, M., Sanchez, G., Nickles, T., and Yarus, M. (1995) Science 267, 643-647.

73. Illangasekare, M., and Yarus, M. (1997) J. Mol. Biol. 268, 631639.

74. Huang, F., and Yarus, M. (1997) Biochemistry 36, 6557-6563.

75. Huang, F., and Yarus, M. (1997) Biochemistry 36, 14107-14119.

76. Lehman, N., and Joyce, G. F. (1993) Nature 361, 182-185.

77. Frank, D. N., and Pace, N. R. (1997) Proc. Natl. Acad. Sci. U.S.A. 94, 14355-14360.

BI012179B 